\title{
Solvent-free Synthesis of Stable Oxaphosphaphenanthrene Derivatives using Multicomponent Reaction of Naphthols
}

\author{
SARA HALLAJIAN ${ }^{*}$, ESKANDAR ALIPOUR ${ }^{1}$, \\ NASER FOROUGHIFAR ${ }^{1}$ and MOHAMMAD A. KHALILZADEH ${ }^{2}$
}

\begin{abstract}
'Department of Chemistry, Islamic Azad University, Tehran North Branch, Tehran, Iran. 2Department of Chemistry, Qaemshahr Branch, Islamic Azad University, Qaemshahr, Iran.

*Corresponding author Email: sara_hallajian@yahoo.com
\end{abstract}

http://dx.doi.org/10.13005/ojc/300348

(Received: June 08, 2014; Accepted: July 23, 2014)

\begin{abstract}
The reaction of dimethyl acetylenedicarboxylate with $\mathrm{OH}$-acid such as 2-naphthol in the presence of trimethyl or triphenyl phosphite under solvent-free conditions produce oxaphosphaphenanthrene derivatives in good yields. Also, the reaction of dimethyl acetylenedicarboxylate and trimethyl phosphite in the presence of 1-naphthol leads to succinate derivatives in excellent yields. Using triethyl phosphite and dimethyl acetylenedicarboxylate in the presence of 1-naphthol or 1-naphthol produces chromene-4-carboxylate derivatives in good yields.
\end{abstract}

Key words: Dimethyl acetylenedicarboxylate; Solvent-free conditions;

Oxaphosphaphenanthrene; 1-naphthol.

\section{INTRODUCTION}

Multi-component reactions (MCRs), due to their productivity, simple procedures, convergence, and facile execution, are one of the best tools in combinatorial chemistry ${ }^{1}$. Therefore, the design of novel MCRs has attracted great attention from research groups working in areas such as drug discovery, organic synthesis and materials science. As a result, the number of new MCRs has grown rapidly². Green chemistry approaches hold out significant potential not only for reduction of byproducts, a reduction in the waste produced, and lowering of energy costs but also in the development of new methodologies toward previously unobtainable materials, using existing technologies ${ }^{3-5}$. Organophosphorus compounds, i.e. those bearing a carbon atom directly bound to a phosphorus atom, are synthetic targets of interest, not least because of their value for a variety of industrial, biological, and chemical synthetic uses [6-8]. As a result, a large number of methods have appeared describing novel syntheses of organophosphorus compounds. There are many studies on the reaction between trivalent phosphorus nucleophiles and $\alpha, \beta$-unsaturated carbonyl compounds in the 
presence of a proton source such as alcohol or phenol $^{9-11}$. We describe herein the reaction of dimethyl acetylenedicarboxylate with triphenyl, triethyl and trimethylphosphit as the P-nucleophile in the presence of $\mathrm{OH}$-acid such as 1-naphthol or 2-naphthol under solvent-free conditions at $70^{\circ} \mathrm{C}$ in excellent yield (Scheme 1).

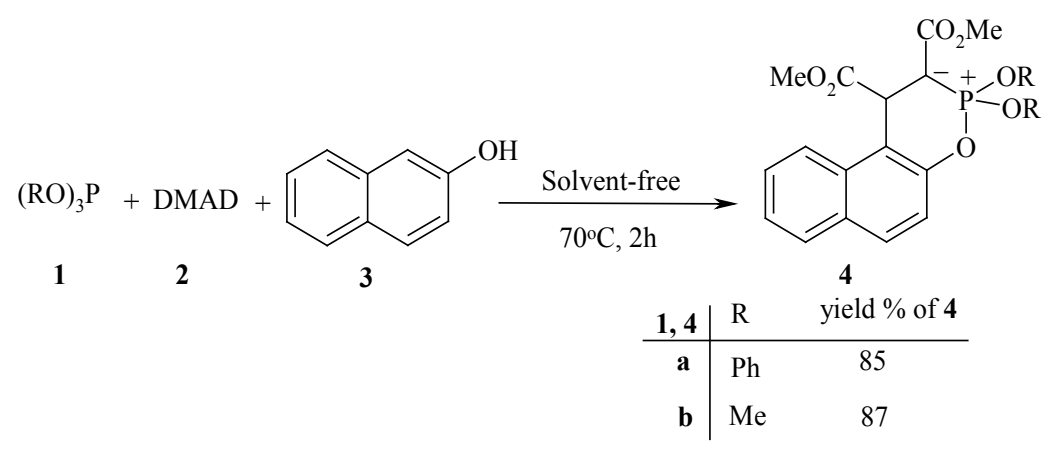

Scheme 1

\section{MATERIAL AND METHODS}

Melting points were measured on an Electrothermal 9100 aparatus. Elemental analyses for the $\mathrm{C}, \mathrm{H}$, and $\mathrm{N}$ were performed using a Heraeus $\mathrm{CHN}-\mathrm{O}-$ Rapid analyzer. Mass spectra were recorded on a FINNIGAN-MATT 8430 spectrometer operating at an ionization potential of $70 \mathrm{eV}$. IR spectra were measured on a Shimadzu IR-460 spectrometer. ${ }^{1} \mathrm{H}$ ,${ }^{13} \mathrm{C}$, and ${ }^{31} \mathrm{P}$ NMR spectra were measured with a BRUKER DRX-500 AVANCE spectrometer at 500.1, 125.8, and 202.4 MHz, respectively. ${ }^{1} \mathrm{H},{ }^{13} \mathrm{C}$, and 31P spectra were obtained for solutions in $\mathrm{CDCl}_{3}$ using TMS as internal standard or $85 \% \mathrm{H}_{3} \mathrm{PO}_{4}$ as external standard. All the chemicals used in this work were purchased from Fluka (Buchs, Switzerland) and are used without further purification.

\section{General procedure for preparation of compounds 4a-b and 9, 17.}

Dimethyl2,2-diphen oxy-4 H-1 - oxa-2/5phosphaphenanthrene-3,4-dicarboxylate (4a)

To a magnetically stirred of $0.28 \mathrm{~g}$ dimethyl acethylenedicarboxylate $2(2 \mathrm{mmol})$ and $0.29 \mathrm{~g}$ 2-naphthol 3 (2 mmol) was added $0.62 \mathrm{~g}$ triphenyl phosphite $1 \mathrm{a}(2 \mathrm{mmol})$ at $70^{\circ} \mathrm{C}$. The reaction mixture was then stirred for $2 \mathrm{~h}$. The reaction mixture was crystallized from diethyl ether. The product $4 \mathrm{a}$ was obtained as colorless crystals, m.p. $178-180^{\circ} \mathrm{C}, 0.90$ g, yield $90 \%$. IR (KBr) $\left(v m a x / \mathrm{cm}^{-1}\right): 1667$, and 1722 $(2 \mathrm{C}=\mathrm{O})$. Anal. Calcd for $\mathrm{C}_{28} \mathrm{H}_{23} \mathrm{O}_{7} \mathrm{P}(502.4)$ : C, 66.93;
$\mathrm{H}$, 4.61. Found: $\mathrm{C}, 66.9 ; \mathrm{H}, 4.7 \% .{ }^{1} \mathrm{H} \mathrm{NMR}(500 \mathrm{MHz}$, $\left.\mathrm{CDCl}_{3}\right): \delta 3.21$ and $3.72(6 \mathrm{H}, 2 \mathrm{~s}, 2 \mathrm{Me}), 5.55(1 \mathrm{H}$, d $\left.{ }^{3} \mathrm{JHP} 33 \mathrm{~Hz}, \mathrm{CH}\right), 6.98-9.20(16 \mathrm{H}, \mathrm{m}, 16 \mathrm{CH}) .{ }^{13} \mathrm{C}$ NMR (125.7 MHz, CDCl$)$ ): $\delta 41.10$ (d, ${ }^{1} \mathrm{JCP} 225 \mathrm{~Hz}$, C), 41.37 (d, $\left.{ }^{2} \mathrm{JCP} 9 \mathrm{~Hz}, \mathrm{CH}\right), 50.32$ and 52.06 (2 OMe), 118.22 (d, ${ }^{3} \mathrm{JPC} 6 \mathrm{~Hz}, \mathrm{CH}$ of $\mathrm{C}_{10} \mathrm{H}_{6}$ ), 120.54 (d, 3JCP $4 \mathrm{~Hz}, 2$ CHortho of Ph), 120.83 (d, 3JPC 9 $\mathrm{Hz}, \mathrm{C}$ of $\mathrm{C}_{10} \mathrm{H}_{6}$ ), 121.50 (d, 3. JPC $4 \mathrm{~Hz}, 2 \mathrm{CHortho}$ of $\mathrm{Ph}), 124.10$, and $125.56\left(2 \mathrm{CH}\right.$ of $\left.\mathrm{C}_{10} \mathrm{H}_{6}\right), 125.92$ and 126.14 (2 CHpara of $\mathrm{Ph}$ ), 127.49 and 128.43 (2 $\mathrm{CH}$ of $\left.\mathrm{C}_{10} \mathrm{H}_{6}\right), 129.71$ (m, $4 \mathrm{CHmeta}$ of $\mathrm{Ph}$ groups), $129.79\left(\mathrm{CH}\right.$ of $\left.\mathrm{C}_{10} \mathrm{H}_{6}\right), 131.13$ and 131.33 (2 $\mathrm{C}$ of $\left.\mathrm{C}_{10} \mathrm{H}_{6}\right), 148.13\left(\mathrm{~d} 2 \mathrm{JPC} 8 \mathrm{~Hz}, \mathrm{C}-\mathrm{O}\right.$ of $\left.\mathrm{C}_{10} \mathrm{H}_{6}\right), 149.96$ (m, 2 Cipso of Ph groups), 168.40 (d 2JPC $17.3 \mathrm{~Hz}$, $\mathrm{C}=\mathrm{O}), 173.32(\mathrm{C}=\mathrm{O}) .{ }^{31} \mathrm{P} \mathrm{NMR}\left(202 \mathrm{MHz} \mathrm{CDCl}_{3}\right)$ : ' 41.54.

Dimethyl 2,2-dimethoxy-4H-1-oxa-2 $\$$-phosphaphenanthrene-3,4-dicarboxylate (4b)

The procedure for preparation of $4 \mathrm{~b}$ was similar to that for $4 a$. Colorless crystals, m.p. 128-130 ${ }^{\circ} \mathrm{C}, 0.64 \mathrm{~g}$, yield $85 \%$. IR $(\mathrm{KBr})\left(v \max / \mathrm{cm}^{-1}\right): 1652$, and $1722(2 \mathrm{C}=\mathrm{O})$. Anal. Calcd for $\mathrm{C}_{18} \mathrm{H}_{19} \mathrm{O}_{7} \mathrm{P}(378.3)$ : C, 57.15; H, 5.06. Found: C, 57.2; H, 5.1\%. ${ }^{1} \mathrm{H}$ NMR $\left(500 \mathrm{MHz} \mathrm{CDCl}_{3}\right): \delta 3.61$ and $3.70(6 \mathrm{H}, 2 \mathrm{~s}, 2 \mathrm{Me})$, 3.65 (3 H, d $\left.{ }^{3} \mathrm{JPH} 13 \mathrm{~Hz}, \mathrm{OMe}\right), 4.07$ (3 H, d ${ }^{3} \mathrm{JPH}$ $13 \mathrm{~Hz}, \mathrm{OMe}$ ), 5.65 ( $\left.1 \mathrm{H}, \mathrm{d}^{3} \mathrm{JHP} 31 \mathrm{~Hz}, \mathrm{CH}\right), 7.26$ (d, 3JHH $9 \mathrm{~Hz}, \mathrm{CH}), 7.45\left(1 \mathrm{H}, \mathrm{t},{ }^{3} \mathrm{JHH} 9 \mathrm{~Hz}, \mathrm{CH}\right), 7.59$ $\left(1 \mathrm{H}, \mathrm{t},{ }^{3} \mathrm{JHH} 9 \mathrm{~Hz}\right), 7.73\left(1 \mathrm{H}, \mathrm{d}^{3} \mathrm{JHH} 9 \mathrm{~Hz}, \mathrm{CH}\right), 7.79$ (1 H, d 3JHH $9 \mathrm{~Hz}, \mathrm{CH}), 8.39\left(1 \mathrm{H}, \mathrm{d}^{3} \mathrm{JHH} 9 \mathrm{~Hz}, \mathrm{CH}\right)$. ${ }^{13} \mathrm{C} \mathrm{NMR}\left(125.7 \mathrm{MHz}, \mathrm{CDCl}_{3}\right): \delta 39.20(\mathrm{~d}, 1 \mathrm{JCP} 222$ $\mathrm{Hz}, \mathrm{C}), 41.37$ (d, ${ }^{2} \mathrm{JCP} 9 \mathrm{~Hz}, \mathrm{CH}$ ), 50.37 and 52.21 (2 
OMe), 55.33 (d, $\left.{ }^{2} \mathrm{JPC} 6 \mathrm{~Hz}, \mathrm{P}-\mathrm{OMe}\right), 55.65$ (d, ${ }^{2} \mathrm{JPC}$ $5 \mathrm{~Hz}, \mathrm{P}-\mathrm{OMe}), 118.35$ (d, 3JPC $6 \mathrm{~Hz}, \mathrm{CH}), 121.29$ (d, $\left.{ }^{3} J P C ~ 9.1 \mathrm{~Hz}, \mathrm{C}\right), 124.40,125.43,127.38,128.40$ and $129.79(5 \mathrm{CH}), 131.13$ and $131.31(2 \mathrm{C}), 148.58$ (d ${ }^{2} \mathrm{JPC} 8 \mathrm{~Hz}, \mathrm{C}-\mathrm{O}$ ), 169.20 (d ${ }^{2} \mathrm{JPC} 18 \mathrm{~Hz}, \mathrm{C}=\mathrm{O}$ ), $174.92(\mathrm{C}=\mathrm{O}) .{ }^{31} \mathrm{P}$ NMR $\left(202 \mathrm{MHz}, \mathrm{CDCl}_{3}\right): \delta 42.53$.

\section{Methyl 3-oxo-2,3-dihydro-1H-benzo[f]chromene- 1-carboxylate (9)}

To a magnetically stirred of $0.28 \mathrm{~g}$ dimethyl acethylenedicarboxylate $2(2 \mathrm{mmol})$ and $0.29 \mathrm{~g}$ 2-naphthol 3 (2 mmol) was added $0.33 \mathrm{~g}$ triethyl phosphite $1 \mathrm{c}(2 \mathrm{mmol})$ at $70^{\circ} \mathrm{C}$. The reaction mixture was then stirred for $5 \mathrm{~h}$. The reaction mixture was crystallized from diethyl ether. (0.49 g, yield 96\%). m.p. 151-152 ${ }^{\circ} \mathrm{C}$, IR $(\mathrm{KBr})\left(\delta \mathrm{max} / \mathrm{cm}^{-1}\right): 1711$, and 1752 (2 C=O). Anal. Calcd for $\mathrm{C}_{15} \mathrm{H}_{12} \mathrm{O}_{4}$ (256.3): C, 70.31; $\mathrm{H}, 4.72$. Found: $\mathrm{C}, 70.1 ; \mathrm{H}, 4.7 \%$. ${ }^{1} \mathrm{H}$ NMR (500 $\left.\mathrm{MHz}, \mathrm{CDCl}_{3}\right)$ : ' $2.82\left(1 \mathrm{H}, \mathrm{dd}^{2} \mathrm{JHH} 16 \mathrm{~Hz}^{3} \mathrm{JHH} 6 \mathrm{~Hz}\right.$, $\mathrm{HCH}), 3.25\left(1 \mathrm{H}, \mathrm{d}^{2} \mathrm{JHH} 16 \mathrm{~Hz}, \mathrm{HCH}\right), 3.65(3 \mathrm{H}, \mathrm{s}$, OMe), 4.60 (1 H, d $\left.{ }^{3} \mathrm{JHH} 6 \mathrm{~Hz}, \mathrm{CH}\right), 7.26$ (d, ${ }^{3} \mathrm{JHH} 9$ $\mathrm{Hz}, \mathrm{CH}), 7.49\left(1 \mathrm{H}, \mathrm{t},{ }^{3} \mathrm{JHH} 8 \mathrm{~Hz}, \mathrm{CH}\right), 7.59(1 \mathrm{H}, \mathrm{t}$, 3.JHH $8 \mathrm{~Hz}), 7.73\left(1 \mathrm{H}, \mathrm{d}^{3} \mathrm{JHH} 8 \mathrm{~Hz}, \mathrm{CH}\right), 7.79(1 \mathrm{H}$, d $\left.{ }^{3} \mathrm{JHH} 8 \mathrm{~Hz}, \mathrm{CH}\right), 8.32\left(1 \mathrm{H},{ }^{3} \mathrm{JHH} 9 \mathrm{~Hz}, \mathrm{CH}\right) \cdot{ }^{13} \mathrm{C}$ $\operatorname{NMR}\left(125.7 \mathrm{MHz}, \mathrm{CDCl}_{3}\right): \delta 31.37\left(\mathrm{CH}_{2}\right), 37.87(\mathrm{CH})$, 52.84 (OMe), $112.73(\mathrm{C}), 117.70,123.27,125.42$, $127.75,128.76$, and $130.65(6 \mathrm{CH}), 130.90,131.00$, and 149.96 ( $3 \mathrm{C}), 166.16$ and $171.22(2 \mathrm{C}=\mathrm{O}) . \mathrm{MS}$, m/z (\%): 256 (M+; 15), 196 (100), 168 (41).

Dimethyl2-(dimethoxy-phosphoryl)-3-(1hydroxy-naphthalene-2-yl)-succinate (17)

To a magnetically stirred of $0.28 \mathrm{~g}$ dimethyl acethylenedicarboxylate $2(2 \mathrm{mmol})$ and $0.29 \mathrm{~g}$ 1-naphthol 16 (2 mmol) was added $0.25 \mathrm{~g}$ trimethyl phosphite $1 \mathrm{~b}(2 \mathrm{mmol})$ at $70^{\circ} \mathrm{C}$. The reaction mixture was then stirred for $4 \mathrm{~h}$. The reaction mixture was crystallized from diethyl ether. The product 17 was obtained as colorless crystals, m.p. $173-185^{\circ} \mathrm{C}, 0.76$ g, yield 96\%. IR (KBr) (vmax/cm-1): $3230(\mathrm{OH}), 1724$ $(\mathrm{C}=\mathrm{O})$. Anal. Calcd for $\mathrm{C}_{18} \mathrm{H}_{21} \mathrm{O}_{8} \mathrm{P}$ (396.3): C, 54.55; $\mathrm{H}, 5.34$. Found: $\mathrm{C}, 54.4 ; \mathrm{H}, 5.3 \%$. ${ }^{1} \mathrm{H} \mathrm{NMR}(500 \mathrm{MHz}$, $\left.\mathrm{CDCl}_{3}\right): \delta 2.85\left(3 \mathrm{H}, \mathrm{d}^{3} \mathrm{JHP} 11 \mathrm{~Hz}, \mathrm{OMe}\right), 3.60$ (3 $\mathrm{H}, \mathrm{s}, \mathrm{OMe}), 3.67$ (3 H, d $3 \mathrm{JHP} 11 \mathrm{~Hz}, \mathrm{OMe}), 3.82$ (3 H, s, OMe), 3.88 (1 H, dd ${ }^{2} \mathrm{JHP} 21 \mathrm{~Hz}{ }^{3} \mathrm{JHH} 12$ $\mathrm{Hz}, \mathrm{CH}), 4.99$ (1 H, dd $\left.{ }^{3} \mathrm{JHH} 12 \mathrm{~Hz}{ }^{3} \mathrm{JHP} 9 \mathrm{~Hz}, \mathrm{CH}\right)$, 7.10-8.42 (6 H, m, $6 \mathrm{CH}), 8.47(1 \mathrm{H}, \mathrm{s}, \mathrm{OH}) .{ }^{13} \mathrm{C} \mathrm{NMR}$ $\left(125.7 \mathrm{MHz}, \mathrm{CDCl}_{3}\right): \delta 44.04(\mathrm{CH}), 48.51$ (d ${ }^{1} \mathrm{JPC} 135$ $\mathrm{Hz}, \mathrm{CH}), 52.79$ (OMe), 52.86 (d 2JPC $7 \mathrm{~Hz}, \mathrm{OMe}$ ),

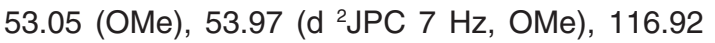

(C), 121.78 and 123.42 (2 CH), 124.60 (C), 125.74 , 126.82 and $127.20(3 \mathrm{CH}), 127.67(\mathrm{C}), 134.20(\mathrm{CH})$, $150.50(\mathrm{C}), 168.24$ (d ${ }^{2} \mathrm{JPC} 5 \mathrm{~Hz}, \mathrm{C}=\mathrm{O}$ ), 173.01 (d $\left.{ }^{3} \mathrm{JPC} 22 \mathrm{~Hz}, \mathrm{C}=\mathrm{O}\right) .{ }^{31} \mathrm{P}$ NMR $\left(202 \mathrm{MHz}, \mathrm{CDCl}_{3}\right): \delta$ 18.56. MS, m/z (\%): 396 (M+, 42), 305 (82), 273 (100), 168 (87), 139(72).

\section{RESULT AND DISCUSSION}

The reaction of dimethyl acetylene dicarboxylate 2 and 2-naphthol 3 in the presence of trimethyl or triphenyl phosphite 1 leads to oxaphosphaphenanthrene-3,4-dicarboxylate derivatives 4 in good yields (Scheme 2). The structures of 4 were determined on the basis of their ${ }^{1} \mathrm{H},{ }^{13} \mathrm{C}$, and ${ }^{31} \mathrm{P}$ NMR spectra, IR spectra, elemental analyses, and mass spectrometric data. The ${ }^{1} \mathrm{H}$ NMR spectrum of $4 \mathrm{a}$ in $\mathrm{CDCl}_{3}$ shows two singlets at $\delta=3.21$ and 3.72 ppm for the methoxy protons and one doublet at $\delta=5.48\left({ }^{3} \mathrm{JPH}=34 \mathrm{~Hz}\right.$ ) for the methine proton, along with multiplets at $\delta=$ 6.98-9.20 for the aromatic protons. Characteristic carbonyl resonances appear clearly at $\delta=168.40$ $\left(\mathrm{d},{ }^{2} \mathrm{JPC}=17 \mathrm{~Hz}\right), 173.32 \mathrm{ppm}$, whereas the ylide carbon atom exhibits resonances at $\delta=41.10$ (d, ${ }^{1} \mathrm{JPC}=225 \mathrm{~Hz}$ ) ppm. The observed ${ }^{1} \mathrm{JCP}$ values are typical of an $\alpha$-ylide ester [12]. The double bond character of the $\mathrm{C}-\mathrm{P}$ bond and the presence of three electronegative oxo substituent on the phosphorus atom increases the ${ }^{1} \mathrm{JCP}$ value.11 Evidence for the presence of an oxaphosphaphenantrene skeleton in $4 \mathrm{a}$ was shown by the ${ }^{13} \mathrm{C}$ signals at $\delta=118.22$ $\left(\mathrm{d},{ }^{3} \mathrm{JCP}=6 \mathrm{~Hz}\right.$ ) for $\mathrm{CH}$ of naphthalene moiety and at $\delta=148.13\left(\mathrm{~d},{ }^{2} \mathrm{JCP}=8 \mathrm{~Hz}\right)$ for the $\mathrm{C}-\mathrm{O}$ carbon of naphthalene. ${ }^{31} \mathrm{P}$ NMR signals was found at $\delta=41.54 \mathrm{ppm}$. The ${ }^{1} \mathrm{H}$ and ${ }^{13} \mathrm{C}$ NMR spectra of $4 b$ were similar to those for $4 a$ except for the phosphoranyl moiety. Although we have not yet established the mechanism of the reaction between dimethylacetylene dicarboxylate and phosphites in the presence of 2-naphthol in an experimental manner, a possible explanation is proposed in (Scheme 2). On the basis of the well established chemistry of phosphorus nucleophiles 2,3 it is reasonable to assume that ylide 4 results from initial addition of the phosphite to DMAD and subsequent protonation of the reactive $1: 1$ adduct, followed by attack of carbon atom of the anion of 2-naphthol 6 to cation 5 to generate ylide 7 which isomerises under the reaction conditions employed to produce the 
oxaphosphorane 8. Elimination of $\mathrm{ROH}$ from 8 leads to product 4 . The reaction between triethyl phosphite

1, dimethylacetylene dicarboxylate 2, and 2-naphthol 3 quantitatively gave product 9 (Scheme 3).

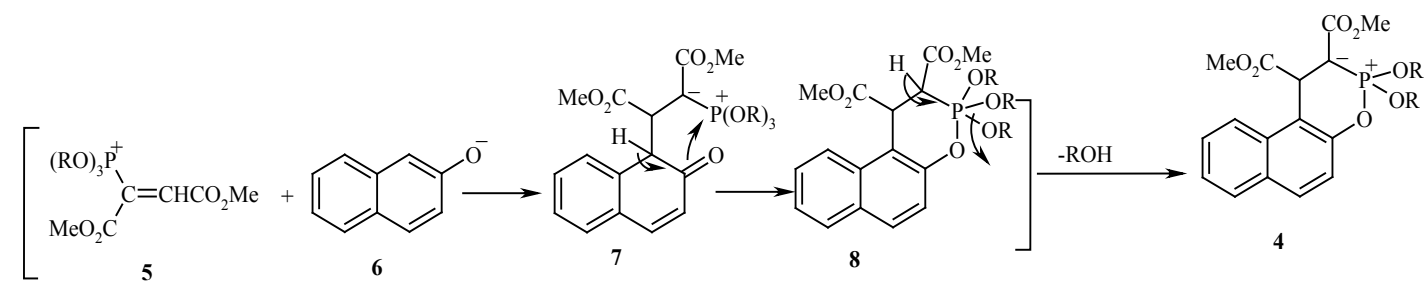

Scheme 2:

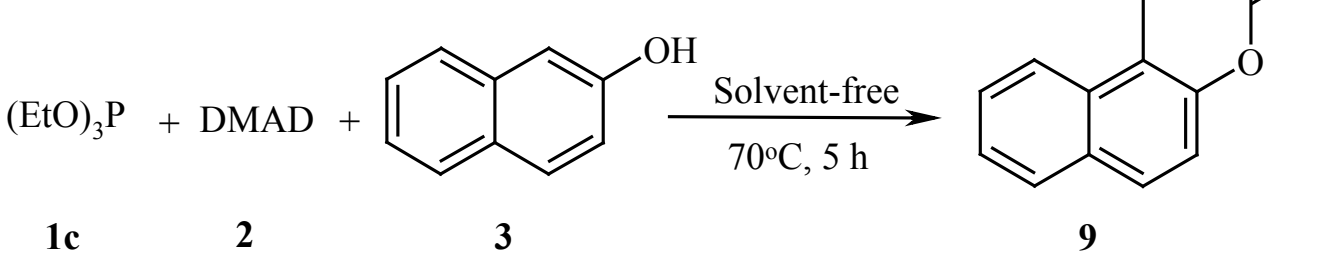

Scheme 3:

The IR spectrum of 9 exhibited the ester and lactone carbonyl groups at 1711 and $1752 \mathrm{~cm}^{-}$ ${ }^{1}$, respectively. The ${ }^{1} \mathrm{H}$ NMR spectrum of 9 showed a double doublet at $\delta=2.82\left({ }^{2} \mathrm{JHH}=16 \mathrm{~Hz},{ }^{3} \mathrm{JHH}\right.$ $=6 \mathrm{~Hz}$ ) for one of the methylene protons. The other methylene proton displayed a doublet $\left({ }^{2} \mathrm{JHH}=16\right.$ $\mathrm{Hz})$ at $\delta=3.25 \mathrm{ppm}$. The methine proton showed a doublet $\left({ }^{3} \mathrm{JHH}=6 \mathrm{~Hz}\right)$ at $\delta=4.60 \mathrm{ppm}$. The coupling constants observed for this AMX system are consistent with a conformation in which theH-C-C-H dihedral angles for the $\mathrm{CH}-\mathrm{CH}_{2}$ moiety are expected to be about $90^{\circ}$ and $30^{\circ}{ }^{12}$. The ${ }^{13} \mathrm{C}$ NMR spectrum of 9 displayed 15 distinct resonance in agreement with the proposed structure. A possible mechanism for the formation of compound 9 is shown in Scheme 4. The oxaphosphorane 12 is formed in similar steps shown for oxaphosphorane 8 in Scheme 2. However, since the ethoxide anion is a weaker living group, cleavage of the phosphorus-oxygen bond of the naphthol residue become favorable, giving dimethyl succinate 15. Lactonization of this hydroxy-ester gave product 9 .

Under similar conditions, the reaction of dimethylacetylene dicarboxylate 2 and trimethyl phosphite 1 in the presence of 1-naphthol 16 gave succinate 17 in good yield (Scheme 5).

The ${ }^{1} \mathrm{H}$ NMR spectrum of 17 displayed signals for vicinal methine protons at $\delta=3.88$ and 4.99, which appeared as two set of double doublets with ${ }^{2} \mathrm{JHP}$ and ${ }^{3} \mathrm{JHP}$ values of 21 and $9 \mathrm{~Hz}$, respectively. The methoxy groups of the phosphoranyl moiety are diastereotopic and show two separate doublets at $\delta=2.85$ and 3.67. The hydroxy proton was observed as a broad singlet at $\delta=8.47$ which disappeared with addition of $\mathrm{D}_{2} \mathrm{O}$. Observation of ${ }^{3} \mathrm{JHH}=12 \mathrm{~Hz}$ for the vicinal

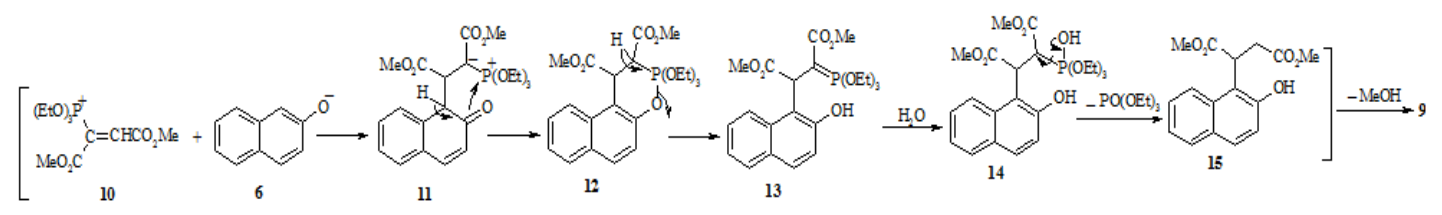

Scheme 4: 
methine protons in 17 indicates the dominance of anti arrangement. A proposed mechanism for the formation of compound 17 is shown in Scheme 4. In conclusion, we found that the reaction of dimethylacetylene dicarboxylate with trimethyl phosphite or triphenyl phosphite in the presence of 2-naphthol leads to functionalized oxaphospha phenanthrenes. The reaction of 1-naphthol with dimethylacetylene dicarboxylate and trimethyl phosphite produces, stereoselectively benzochromene derivative in high yield. The addition reaction of triethyl phosphite, dimethylacetylene dicarboxylate, and 1-naphthol or 2-naphthol leads quantitatively to benzochromene derivatives. The present method carries the advantage that, not only is the reaction performed under solvent-free conditions, but also the substances can be mixed without any activation or modification.<smiles>CO[14C](=O)c1ccc2cccc(O)c2c1C(C(C)=O)C(C(C)=O)C(C(C)=O)C(C)=O</smiles>

Scheme 5:

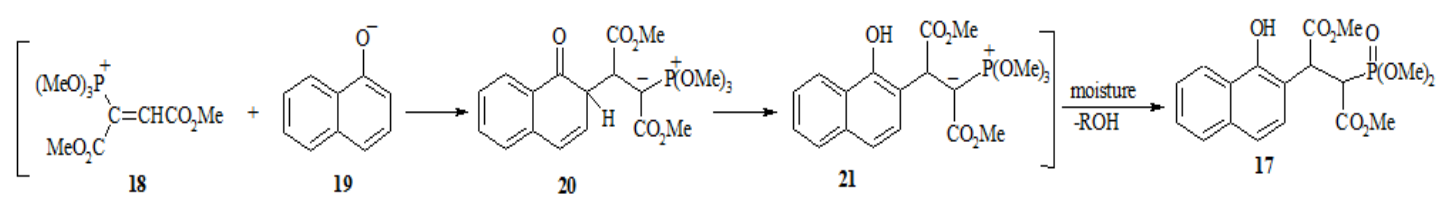

Scheme 6:

\section{REFERENCES}

1. Terrett N. K., Combinatorial Chemistry, Oxford University Press. New York,(1998)

2. (a) Orru, R. V. A.; Greef, M.Synthesis. 2003,10 ,1471-1499

(b) Do"mling, A.Curr. Opin. Chem. Biol.2002, 6, 306-313

(c) Bienayme, H.; Hulme, C.; Oddon, G.; Schmitt, P.Chem. Eur. J. 2000,6, 3321-3329

(d) Do"mling, A. Chem. Rev.2006, 106, 17-89

(e) Zhu J. and Bienayme' H.,Multicomponent Reactions, Wiley-VCH.weinheim, (2005)

3. Anastas P.andWilliamson T., Green Chemistry: Frontiers in Benign ChemicalSynthesis and Procedures, Oxford Science Publications. New York, (1998)

4. Cave, G. W. V.; Raston, C. L.; Scott, J. L. Chem. Commun. 2001,21, 2159-2169

5. Sheldon R. A., As estimated by determination of E-factor,Vol. 12.; Chem. Ind. (1997)

6. Corbridge D. E. C., Phosphorus: An Outline of Its Chemistry, Biochemistry and Uses, 5th
ed.;Elsevier. Amesterdam, 1995.

7. Engle R., Synthesis of Carbon-Phosphorus Bond, CRC Press. Boca Raton, FL, 1988.

8. Cadogan J. I. G., Organophosphorus Reagents in Organic Synthesis, Academic Press. New York, 1977.

9. Hudson H. R., in The Chemistry of Organophosphorus Compounds, Primary, Secondary and Tertiary Phosphines, Polyphosphines and Heterocyclic Organophosphorus(III) Compounds, Vol. I.; John Wiley. New York, 1990.

10. George, M. V.; Khetan, S. K.; Gupta, R. K.Adv. Heterocycl. Chem.1976, 19, 354-355

11. Burgada, R.; Leroux, Y.; Zabloka, M.; El Khoshnieh, Y. U. Tetrahedron Lett.1981,22, 33-35

12. Silverstein R. M., Bassler, C. G. and Morrill T. C., Spectroscopic Identification of Organic Compounds, 5th ed.;John Wiley. New York, 1992 